\title{
Long-term analysis of soil water conservation and crop yield under different tillage systems in Mediterranean rainfed conditions
}

\author{
Jorge Lampurlanés $^{\mathrm{a}^{*}}$, Daniel Plaza-Bonilla ${ }^{\mathrm{b}}$, Jorge Álvaro-Fuentes ${ }^{\mathrm{c}}$, Carlos Cantero-Martínez ${ }^{\mathrm{d}}$ \\ ${ }^{a}$ Departamento de Ingeniería Agroforestal. Unidad Asociada EEAD-CSIC, Agrotecnio, Universidad de Lleida, Avda. \\ Rovira Roure, 191, 25198, Lleida, Spain. \\ ${ }^{b}$ INRA, UMR-AGIR 1248, 24 Chemin de Borde Rouge - Auzeville, CS 52627, 31326 Castanet Tolosan cedex, France. \\ ${ }^{c}$ Departamento de Suelo y Agua, Estación Experimental de Aula Dei, Consejo Superior de Investigaciones \\ Científicas (EEAD-CSIC). P.O. Box 13034, 50080, Zaragoza, Spain. \\ ${ }^{d}$ Departamento de Producción Vegetal y Ciencia Forestal. Unidad Asociada EEAD-CSIC, Agrotecnio, Universidad de \\ Lleida, Avda. Rovira Roure, 191, 25198, Lleida, Spain.
}

Please, cite this article as:

Lampurlanés, J., Plaza-Bonilla, D., Álvaro-Fuentes, J., Cantero-Martínez, C., 2016. Long-term analysis of soil water conservation and crop yield under different tillage systems in Mediterranean rainfed conditions. Field Crops Res. 198, 59-67, http://dx.doi.org/10.1016/j.fcr.2016.02.010

(C) 2016. This manuscript version is made available under the CC-BY-NC-ND 4.0 license http://creativecommons.org/licenses/by-nc-nd/4.0/

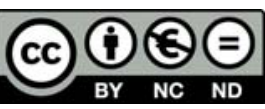

\footnotetext{
*Corresponding author: Jorge Lampurlanés $(\mathrm{PhD})$

E-mail: jlampur@eagrof.udl.es

Phone number: (+34) 973702537
}

Fax number: (+34) 973702673 


\section{Abstract}

This study focuses on the quantification of soil water storage and crop yield under different tillage systems in dryland semiarid Mediterranean conditions. Three long-term tillage experiments based on cereal production were initiated in 1987, 1990 and 1992, at three different locations in the Ebro river valley (NE Spain): El Canós, Selvanera and Agramunt, with an increasing degree of aridity. Different tillage intensities were compared in each experiment using different implements: no tillage (NT), minimum tillage (MT), chisel (Ch), subsoiler up to $25 \mathrm{~cm}$ depth (Sub-25) and up to 50 $\mathrm{cm}$ (Sub-50), and mouldboard plough (Mb). Soil water content (SWC) up to $100 \mathrm{~cm}$, soil water storage (SWS), precipitation storage efficiency (PSE) and crop yield were quantified during 8 (El Canós) and 19 years (Selvanera and Agramunt). The use of MT (at Selvanera) and NT (at El Canós and Agramunt) led to the highest SWC after the storage period (i.e. from previous harvest to crop tillering), with a major role played by the storage of water at deep soil layers. At Agramunt, Mb presented the lowest SWS when compared to Ch, Sub-50 and NT, and, consequently, the lowest post-tillering evapotranspiration. On the contrary, no differences were found between tillage systems on SWS at El Canós or at Selvanera. Significant yield differences were found at Agramunt being: NT $>$ Sub-50 $>\mathrm{Ch}=\mathrm{Mb}$. These differences were especially important in years with mean yield below $2000 \mathrm{~kg} \mathrm{ha}^{-1}$, in which NT obtained the highest productions. At Selvanera yield was greater under conservation tillage (NT, MT) than under intensive tillage (Sub-50). Contrarily, no yield differences were found between tillage systems at El Canós, the site with the lowest water deficit, where crop residues were removed. A strong linear relationship was found between SWS and yield at Agramunt and Selvanera. At Agramunt the relationship presented a greater slope under Mb. In this site, in years with previous harvest-to-tillering SWS below $100 \mathrm{~mm}$ and with precipitation over $100 \mathrm{~mm}$ between tillering and anthesis, yields were, as an average, $1245 \mathrm{~kg} \mathrm{ha}^{-1}$ higher than in standard years. This study demonstrates that under semiarid rainfed conditions, soil water storage increases with the use of conservation tillage systems, being amplified with the degree of aridity of the site. The 
relationship between water stored in the soil and crop yield and its reliability is site-specific. Once determined, it could be used to predict yield at the end of the vegetative phase of the crop to help take management decisions.

Keywords: Soil water storage; No-tillage; Conservation tillage; Intensive tillage; Semiarid dryland. 


\section{Introduction}

The Mediterranean climate is defined by low and variable rainfall. The Ebro river valley (NE Spain) is representative of the arid and semiarid areas of the Mediterranean region. In these areas about $75 \%$ of the precipitation falls in two periods, from September to December and from April to May, with higher uncertainty in the second one (Austin et al. 1998). In the autumn and winter months, cold temperatures, low radiation, high relative humidity and low wind-speeds result in low evaporation rates. From September to January rainfall exceeds evaporation and water is stored in the soil, considering this period as the "soil water recharge period". In the spring and summer months, however, low rainfall and enhanced evaporation by increased radiation and wind-speeds cause high water deficit for agricultural activity (Cooper et al., 1987). Under these conditions, fallow and intensive tillage systems had been a traditional strategy to capture and store out-of-season water. However, in the last two decades conservation tillage (CT) has been increasingly adopted by the farmers as a new alternative to increase water availability and reduce costs (Cantero-Martínez and Gabiña, 2004) making possible the intensification of the cropping system. Regarding to this last, Álvaro-Fuentes et al. (2008, 2009b), in this same geographical area, concluded that the suppression of long fallow periods and the use of no-tillage increases the stability of the soil structure and leads to soil carbon $(\mathrm{C})$ sequestration.

According to Peterson and Westfall (2004), sustainable cropping under water limiting conditions involves maximizing precipitation use efficiency (PUE). PUE is the quotient between yield $(\mathrm{Y})$ and rainfall $(\mathrm{R}): P U E=\frac{Y}{R}$

We can expand this expression by adding the terms water use (WU) and soil water storage (SWS) in this way: $P U E=\frac{Y}{W U} \cdot \frac{W U}{S W S} \cdot \frac{S W S}{R}$

Y over WU is water use efficiency (WUE), and SWS over R is precipitation storage efficiency (PSE) (Tanaka and Anderson, 1997). The term WU over SWS can be assumed to be 1 as a 
mean in semiarid environments (crops tend to use all the water available in the soil). We can simplify then PUE as: $P U E=W U E \cdot P S E$

CT can have a positive effect on PUE because it can improve both WUE and PSE by increasing the infiltration to runoff ratio (Unger and McCalla, 1980) and reducing evaporation (Bond and Willis, 1971). CT can also play an important role to stabilize yields by increasing water stored in the soil during the months of lower evaporative demand by increasing infiltration (Unger and McCalla, 1980), depending on the amount of crop residues left on the soil surface (Smika and Unger, 1986; Tanaka and Anderson, 1997). The improvement of soil structure by the reduction of tillage and the increase of soil organic matter content under CT can also increase the available water capacity of the soil (Hudson, 1994; Plaza-Bonilla et al. 2013).

Different short-term studies in the area proved that CT stored more water than more intensive tillage systems (Lampurlanés et al., 2002; Moret et al. 2006). These results suggest that CT can play an important role in improving the water-trapping process during the soil water recharge period in Mediterranean conditions. As these studies were limited in time (included no more than 4 years), to confirm this hypothesis we present here the results of three experiments with 9,24 and 27 years of continuous CT use (6 and 19 years of water storage data), the longest tillage experiments in the area. The effect of CT on productivity and water use efficiency were already published (Cantero-Martínez and Lampurlanés, 2007). This work aimed at quantifying the long-term effects of different tillage systems on soil water storage and precipitation storage efficiency and their relationships with crop yield under dryland semiarid Mediterranean conditions. 


\section{Materials and methods}

\subsection{Climate and soils of the experimental area}

The study was conducted in the Ebro valley (NE Spain). In this area climate is classified as Temperate Continental Mediterranean (Papadakis, 1966) and is representative of a wide extension of the Mediterranean region. Annual rainfall is below $350 \mathrm{~mm}$ in the centre of the valley, but reaches $650 \mathrm{~mm}$ near the surrounding mountains.

The experimental fields for this study were established at three locations in the Ebro Valley, all three in the Lleida province (Spain): Agramunt, Selvanera, and El Canós, with different long-term mean annual precipitation ( 382 to $450 \mathrm{~mm}$ ), and annual water deficit (350 to $423 \mathrm{~mm}$ ). The soils are classified as Fluventic Xerochrept at Selvanera and El Canós, and Typic Xerochrept at Agramunt (Soil Survey Staff, 1999). Soil texture is loamy at Selvanera, loamy fine at El Canós, and clay-siltloamy at Agramunt. Plant-available water-holding capacity, up to the sampling depth $(1 \mathrm{~m})$, reaches $206 \mathrm{~mm}$ at Agramunt, $213 \mathrm{~mm}$ at Selvanera, and $225 \mathrm{~mm}$ at El Canós. More information about sites, climate and soils can be found in Table 1 .

\subsection{Experimental design and tillage systems}

The experimental plots were established in 1987 at Selvanera and 1990 at Agramunt, by the Extension Services of the Spanish Ministry of Agriculture. At El Canós the study was initiated in 1992 by the Agronomy and Environment in Mediterranean Agroecosystems Research Group of the University of Lleida that manages the three experiments since 1995. The experiments consisted on a randomised block design with three replications at Selvanera and four at El Canós and Agramunt. Plot size was $(50 \times 7 \mathrm{~m}) 350 \mathrm{~m}^{2}$ at Selvanera, $(30 \times 6 \mathrm{~m}) 180 \mathrm{~m}^{2}$ at El Canós and $(50 \times 9 \mathrm{~m}) 450 \mathrm{~m}^{2}$ at Agramunt.

Six tillage systems, mouldboard $(\mathrm{Mb})$ plough, deep subsoiling to $50 \mathrm{~cm}(\mathrm{Sub}-50)$, shallow subsoiling to $25 \mathrm{~cm}$ (Sub-25), chisel (Ch), minimum tillage (MT) and NT were compared across the sites: NT, MT and Sub-50 at El Canós; NT, Ch, Sub-50 and Mb at Agramunt; and NT, MT, Sub-25 
and Sub-50 at Selvanera. Intensive tillage $(\mathrm{Mb})$ consisted of one mouldboard ploughing $(30-35 \mathrm{~cm}$ depth) plus one or two cultivator passes (15 cm depth) in September. Subsoilings (Sub-50 and Sub25) were carried out in August to depths of 40-50 and 20-25 cm, respectively. The practice of a shallow subsoiling at $25 \mathrm{~cm}$ depth was established by the farmer as a way to reduce fuel consumption. Ch consisted of one pass with a chisel plough $(20 \mathrm{~cm}$ depth) before sowing. The tillage systems enumerated above were completed with a single cultivator pass when soil conditions were appropriate for sowing. MT comprised one cultivator pass $(10-15 \mathrm{~cm}$ depth) in the same soil moisture condition as the Sub-50 and Sub-25. In NT, crops were sown without tillage (direct drilling) after plots were sprayed with herbicide, $1.5 \mathrm{~L} \mathrm{ha}^{-1}$ of $36 \%$ glyphosate $[\mathrm{N}-$ (phosphonomethyl)-glycine] plus $1 \mathrm{~L}$ of 40\% MCPA [2-(4-chloro 2-methylphenoxy) acetic acid]. In some years, a roller was used to break clods and promote germination in all systems where some kind of tillage was employed. Sowing was performed with a no-till disc drill in Agramunt and with a no-till hoe drill in Selvanera and El Canós, properly regulated to the soil conditions of each treatment. In the analyses, MT and NT were considered CT systems while the other four systems were considered as intensive tillage treatments.

\subsection{Cropping systems and crop technology}

Different crop sequences were maintained at individual sites throughout the study according to their yield potential. These crop sequences are shown in Table 2. At Selvanera, owing to its climatic conditions, canola (Brassica napus L.) was sufficiently productive to be alternated with winter cereals (barley, Hordeum vulgare L.; and wheat, Triticum aestivum L.) one each four years after 1996. Moreover, since the 2011-12 cropping season the rotation was diversified with the introduction of winter pea (Pisum sativum L.). At El Canós and Agramunt, since growing canola was extremely uncertain (Álvaro-Fuentes et al., 2009a) only cereals were grown. Barley was grown every year at El Canós, while at Agramunt, it was alternated with wheat and triticale since the 2000-2001 season. 
Crop management practices, apart from tillage, were similar in all three experiments. Crops were sown earlier at Selvanera (early October for barley and wheat and end of September for canola) than at El Canós and Agramunt (end of October to end of November) because September rainfall in Selvanera permits earlier soil preparation and weed control. Planting density ranged between 400 and 500 seeds $\mathrm{m}^{-2}$ for barley and wheat and 100-120 seeds $\mathrm{m}^{-2}$ for canola in rows spaced 17-19 cm apart.

Fertilization was performed according to crop requirements and soil tests. Cow manure and

pig slurry $\left(60 \mathrm{~kg} \mathrm{~N} \mathrm{ha}^{-1}\right)$ were annually spread before sowing at Selvanera and Agramunt, respectively. Top dressing mineral fertilizer (50-60 $\left.\mathrm{kg} \mathrm{N} \mathrm{ha}^{-1}\right)$ using ammonium nitrate (33\%) was spread on the soil surface at tillering in Selvanera and, if needed according to soil analyses, at the same growth stage $60 \mathrm{~kg} \mathrm{~N}$ ha $^{-1}$ of ammonium nitrate was applied at Agramunt. At El Canós, $50 \mathrm{~kg}$ $\mathrm{N} \mathrm{ha}^{-1}$ of mineral fertiliser was applied, one-third before sowing using ammonium sulphate (21\%) and two-thirds at the beginning of tillering using ammonium nitrate $(33.5 \%)$. Additional $\mathrm{P}$ and $\mathrm{K}$ fertilizers were applied before sowing following soil tests at El Canós.

After the emergence of the crop and before tillering, grass and broadleaf weeds were controlled by herbicides. A rotation of products, of low toxicity, was applied only when necessary. No treatments were required for pests or diseases.

Grain harvest was carried out with a standard medium sized combine that chopped and spread straw at Agramunt. At El Canós and Selvanera cut straw was removed because of the large amounts that were produced in some years. At these sites, however, the stubble was cut higher than traditionally-practiced by farmers (i.e. $20-25 \mathrm{~cm}$ ).

\subsection{Measurements and derived variables}

Rainfall and temperature were monitored daily at standard weather stations situated at or near the experimental fields. Soil cores were taken from 0-25, 25-50, 50-75 and 75-100 cm depth before sowing, at tillering, anthesis and after harvest every year, in two replicates per plot. Soil water 
content (SWC) was determined gravimetrically on these cores after drying them to constant weight in a forced-draft oven at $105^{\circ} \mathrm{C}$ (Campbell and Mulla, 1990).

The growing season was divided into two periods: the water storage period, from previous harvest to tillering, and the water consumption period, from tillering to harvest, both divided again in two sub-periods as shown in Fig. 1. For every period or sub-period, soil water storage (SWS) was calculated as $\mathrm{SWC}$ at the end $\left(\mathrm{SWC}_{\mathrm{e}}\right)$ minus $\mathrm{SWC}$ at the beginning $\left(\mathrm{SWC}_{\mathrm{b}}\right)$. Precipitation storage efficiency (PSE) was calculated as the quotient between SWS and rainfall (R), negative values were set to 0 and values over 100 were set to 100 . Evapotranspiration (ET) was calculated with a simplified soil water balance for each sub-period: $\mathrm{SWC}_{\mathrm{b}}+\mathrm{R}=\mathrm{ET}+\mathrm{SWC}_{\mathrm{e}}$ (in the three sites slope can be considered negligible, preventing runoff and there is not enough rain for deep drainage). Then, $\mathrm{ET}=\mathrm{R}+\mathrm{SWC}_{\mathrm{b}}-\mathrm{SWC}_{\mathrm{e}}=\mathrm{R}-\mathrm{SWS}$. Crop yield was determined weighing the grain obtained from the harvest of each plot and converting it to $10 \%$ humidity.

\subsection{Statistical analysis}

Linear regression and variance analyses were computed using the " $\mathrm{lm}$ " function of the R language for statistical computing (R Development Core Team, 2015) and the "Anova" function of the "car" package (Fox and Weisberg, 2011) to test the main effects of the year (YEAR) and tillage system (TIL) and its interaction. Mean separations for significant effects were conducted using the least significant diference (LSD) contrast $(\mathrm{P}=0.05)$ with the "LSD.test" function of the "agricolae" package of R (de Mendiburu, 2014). 


\section{Results}

\subsection{Precipitation during the experimental period}

July to June precipitation was highly variable during the experimental years (Fig. 2). The driest seasons (below $300 \mathrm{~mm}$ ) were 2004-05, 2005-06, 2010-11 and 2011-12. The wettest (over 500 mm) were 1995-96, 1996-97, 2003-04, and 2009-10. Mean annual precipitation over the studied seasons was $427 \pm 94 \mathrm{~mm}$ at El Canós, $421 \pm 123 \mathrm{~mm}$ at Agramunt, and $398 \pm 100 \mathrm{~mm}$ at Selvanera, with an annual water deficit of 370, 434 and $402 \mathrm{~mm}$ respectively. However, taking into account ET, from driest to wettest the sites ordered Agramunt $>$ Selvanera $>$ El Canós. In addition, the precipitation distribution pattern was different at El Canós, compared with Agramunt and Selvanera (Fig. 3). Up to $68 \%$ of the precipitation $(293 \mathrm{~mm}$ ) fell during the storage period at El Canós whereas only $52 \%$ at Agramunt $(230 \mathrm{~mm})$ and $55 \%$ at Selvanera $(221 \mathrm{~mm})$. At El Canós, intense rainfall in autumn flooded the experimental field in two seasons: 1994-95 (sowing had to be repeated in February) and 1995-96 (no yield was obtained).

\subsection{Soil water content, soil water storage and precipitation storage efficiency}

Significant differences between tillage systems were found on SWC at El Canós at sowing, tillering and harvest and throughout the season at Agramunt and Selvanera (Table 3). On average (all cropping seasons), NT showed the highest SWC at El Canós and Agramunt whereas MT at Selvanera. TIL*YEAR interaction was significant at Agramunt and Selvanera at sowing, and tillering. At Agramunt, at tillering, the stage with the greatest SWC, NT presented greater SWC than Mb in 11 out of 19 years (Fig. 4a). These differences were found not only at the surface but throughout the soil profile, especially in seasons with more than $200 \mathrm{~mm}$ rainfall during the storage period. At Selvanera (Fig. 4b), NT overpassed the most intensive tillage system (i.e. Sub-50) only in 4 out of 17 years. No significant differences were found in the remaining years.

As an average of the different tillage systems and years, the SWS and the PSE during the water storage period (i.e. from previous harvest to tillering) was lower at El Canós (83 mm and 32\% 
respectively, Table 4) and Agramunt (81 mm and 37\% respectively, Table 5) than at Selvanera (99 $\mathrm{mm}$ and $49 \%$ respectively, Table 6). PSE was very similar at all locations during the previous harvest to sowing sub-period (around 30\%), but greater and different at the sowing to tillering sup-period: 38\% at El Canós (Table 4), 46\% at Agramunt (Table 5), and 61\% at Selvanera (Table 6).

At El Canós, no differences were found in SWS or PSE between tillage systems (Table 4). Contrarily, great differences were found for both variables at Agramunt (Table 5). On the whole period, Mb was the system with the lowest mean SWS (70 mm) compared with Sub-50 (82 mm), Ch (84 mm), and NT $(87 \mathrm{~mm})$. At Agramunt, 13 out of 19 years received less than $250 \mathrm{~mm}$ of precipitation during the soil storage period (Fig. 4a). In half of those years (i.e. 6 out of 13), Mb stored significantly less water than NT. Accordingly, mean PSE was lower for Mb (32\%) than for Sub-50 (37\%), Ch (38\%) or NT (42\%). Year by year comparisons of tillage systems for PSE followed the same pattern as SWS: Mb showed significantly lower values than the other tillage systems in half of the years with less than $250 \mathrm{~mm}$ rainfall during the soil recharge period. At Selvanera (Table 6), differences between tillage systems on SWS were not statistically significant, but NT showed significantly greatest PSE. Across sites and years, SWS was positively related with precipitation during the storage period (regression coefficients of $0.15^{* * *}$ at El Canós, $0.32^{* * *}$ at Agramunt, and $0.40^{* * *}$ at Selvanera), and negatively related with SWC at previous harvest (regression coefficients of $-0.95^{* * *}$ at El Canós, $-0.57^{* * *}$ at Agramunt, and $-0.67^{* * *}$ at Selvanera).

\subsection{Post-tillering evapotranspiration, yield and its relationships with previous variables}

During the consumption period, ET was $227 \mathrm{~mm}$ at El Canós (Table 4), $286 \mathrm{~mm}$ at Agramunt (Table 5), and $298 \mathrm{~mm}$ at Selvanera (Table 6), as an average of tillage systems and years. Differences between tillage systems in post-tillering ET were found only at Agramunt were Mb showed the lowest values (Table 5): 14, 17 and $22 \mathrm{~mm}$ less than Sub-50, Ch and NT, respectively. Significant differences between tillage systems on post-tillering ET were observed in 9 out of 19 years. In seven of those nine years, NT presented greater post-tillering ET than Mb. Moreover, post- 
tillering ET was positively related to SWS at El Canós (regression coefficient $1.05^{* * *}, \mathrm{R}^{2}=0.75^{* * *}$ ), at Agramunt (regression coefficient $0.75^{* * *}, \mathrm{R}^{2}=0.16^{* * *}$ ) and at Selvanera (regression coefficient $\left.0.86^{* * *}, \mathrm{R}^{2}=0.33^{* * *}\right)$.

Mean yield decreased from $4310 \mathrm{~kg} \mathrm{ha}^{-1}$ at Selvanera (Table 6) to $3239 \mathrm{~kg} \mathrm{ha}^{-1}$ at El Canós (Table 4), being the lowest at Agramunt: $2644 \mathrm{~kg} \mathrm{ha}^{-1}$ (Table 5). Significant differences between tillage systems on yield were found at Agramunt which, from greatest to lowest, were: NT $>$ Sub-50 $>\mathrm{Ch}=\mathrm{Mb}$, ranging between 2929 and $2430 \mathrm{~kg} \mathrm{ha}^{-1}$ (Table 5). At Selvanera, significant yield differences were observed between conservation tillage (NT: $4393 \mathrm{~kg} \mathrm{ha}^{-1}$, Ch: $4355 \mathrm{~kg} \mathrm{ha}^{-1}$ ) and intensive tillage (Sub-25: $4269 \mathrm{~kg} \mathrm{ha}^{-1}$, Sub-50: $4219 \mathrm{~kg} \mathrm{ha}^{-1}$ ) systems (Table 6). Contrarily, no significant yield differences between tillage systems were found at El Canós (Table 4).

On a yearly analysis, yield differences between tillage systems were found at Agramunt and Selvanera (Fig. 5). At Agramunt, NT over yielded the other tillage systems in 5 out of 19 years and presented the lowest yield only in one of them (1998-99, Fig. 5b). Mb over yielded the rest of treatments in two consecutive years (1997-98 and 1998-99) and under yielded in 8 years. In this site, differences between tillage systems were especially important in years with mean yield below 2000 $\mathrm{kg} \mathrm{ha}^{-1}(2000-01,2004-05,2005-06,2007-08,2010-11$ and 2011-12), the driest of the series, where NT obtained the highest yields (Fig. 5b). At Selvanera, differences between tillage systems were found in the less-productive years (2003-04, 2004-05, 2007-08 and 2011-12) but without consistent advantage of any tillage system (Fig. 5c).

Yield was positively related to SWS at Agramunt and Selvanera (Fig. 6). At Agramunt two groups of years had to be considered to properly model this relationship (Fig 6-a): the standard (mean yield of $2191 \mathrm{~kg} \mathrm{ha}^{-1}$ ) and the over-yielding years (mean yield of $3436 \mathrm{~kg} \mathrm{ha}^{-1}$ ). On the standard years (10 over 18) the slope of the relationship was steepest for $\mathrm{Mb}\left(27.8 \mathrm{~kg} \mathrm{ha}^{-1} \mathrm{~mm}^{-1}\right)$ than for the other tillage systems $\left(18 \mathrm{~kg} \mathrm{ha}^{-1} \mathrm{~mm}^{-1}\right)$. The over-yielding years ( 8 over 18$)$ were the ones with less than $100 \mathrm{~mm}$ SWS up to tillering and more than $100 \mathrm{~mm}$ of precipitation during the 
tillering to anthesis period. In these years, the intercept of the yield to SWS relationship was around $2000 \mathrm{~kg} \mathrm{ha}^{-1}$ higher than in the standard years, and the slope $12.1 \mathrm{~kg} \mathrm{ha}^{-1} \mathrm{~mm}^{-1}$. At Selvanera, the slope of the relationship was $30.4 \mathrm{~kg} \mathrm{ha}^{-1} \mathrm{~mm}^{-1}$ irrespective of the tillage system (Fig 6-b). No significant relationship was found between SWS and yield at El Canós. At Selvanera, the yield to SWS relationship had the same slope for the different crops, but $1800 \mathrm{~kg} \mathrm{ha}^{-1}$ lower intercept for canola, the crop with lower yield potential. At Agramunt, in the standard years wheat had a significantly greater slope than barley or triticale which implies higher sensitivity of its yield to SWS. Similarly than in Selvanera, no significant tillage and crop interaction on the slope of the linear relationship between yield and SWS was found in Agramunt. 


\section{Discussion}

This study was carried out at three different locations within an aridity gradient to be representative of the wide variability in Mediterranean areas. The results obtained highlight the great effect of site-specific conditions like rainfall distribution and soil management system (tillage operations and residue management) on the soil water storage process and, consequently, on yield.

Yield differences between tillage systems increased with aridity. At Agramunt, the driest site according to the annual water deficit, greater yield differences were found between tillage systems, especially in years with yields below $2000 \mathrm{~kg} \mathrm{ha}^{-1}$, the driest of the series. In the semiarid areas, under greater water deficits, a greater crop response to the use of conservation tillage systems is usually found (e.g. Cantero-Martínez et al., 2003; Hernanz et al., 2014). This shows the potential of conservation tillage systems which overpass the conventional ones in semiarid conditions.

El Canós, the place with the greatest amount of precipitation during the storage period, showed the lowest PSE because most of this rain falls during the summer months, the period with the highest evaporative demand (i.e. from previous crop harvest to sowing). Therefore, the reduction of the evaporation during this period would be crucial to increase the amount of water available for the crop. As crop residues were removed after harvest in this site, maintaining a greater amount of them over the soil or create a tillage mulch should be considered to increase soil water storage under conditions of high evaporative demand (Lampurlanés et al., 2002; Montenegro et al., 2013). Soil cover with crop residues not only reduces evaporation but mitigates significantly the risks of soil erosion, an aspect of a paramount importance under Mediterranean rainfed agriculture (Delgado et al., 2013; García-Ruiz, 2010). However, to be useful, crop residues must be properly managed to maximize the amount of water stored in the soil. Regarding to this, in a recent work, Swella et al. (2015) concluded that tall-standing residue increases the interception of rainfall and allows a greater penetration of water into the soil when compared to leaving most of the residues horizontal. However, in the least productive environments not enough plant residues could be available to 
adequately cover the soil. In turn, under smallholder agriculture, the competition with other residue uses impedes the proper application of no-tillage practices (Lahmar et al., 2012; Plaza-Bonilla et al. 2015). Under those scenarios, or in the case of soil surface seals, some authors advocate for some tillage (Radford et al., 1992; Thomas et al., 2007). Similarly, in some conditions, secondary tillage appears to have a positive effect on soil water conservation at the end of the fallow (Moret et al., 2006).

During the sowing to tillering period precipitation was similar at the three sites (around 140 $\mathrm{mm}$ ) but SWS was, on average 22/44 mm greater and PSE 15/23\% greater at Selvanera than at Agramunt and El Canós, respectively. That result could be explained by differences between sites in evaporative demand (higher at Agramunt), SWS in the previous harvest to sowing period (higher at El Canós), the amount of residue (higher at Selvanera despite being partially removed), and aggregate stability at the soil surface, which is significantly reduced when tillage is used, especially systems that involve any degree of soil inversion (Plaza-Bonilla et al. 2010), which could have affected water infiltrability (that is the case of Agramunt were Mb was used).

Differences between tillage systems on SWS or PSE were appreciable at Agramunt, small at Selvanera and negligible at El Canós. In general, SWS and PSE increased as tillage intensity decreased. The lower values were quantified under $\mathrm{Mb}$, only tested at Agramunt. $\mathrm{Mb}$ is not well suited for the dryland Mediterranean agroecosystems because no residues are left over the soil surface, an aspect that could have been aggravated due to the soil texture of Agramunt with $60 \%$ of silt, being prone to crust formation (Pagliai et al. 1995). Probably, at Agramunt, lower infiltration rates under $\mathrm{Mb}$ promoted water ponding and, concomitantly, evaporation, and limited water availability for the crop. As it has been found in the area, the use of mouldboard plough reduces the stability of the aggregates decreasing the ability of the soil structure to recover after disturbances such as high intensity rains, typical of the Mediterranean climate (Plaza-Bonilla et al. 2010, 2013; Álvaro-Fuentes et al. 2008). Moreover, the lower soil water content under Mb impaired proper crop 
establishment in some years, resulting in low yields. Despite not studied here, other aspects such as the reduction of soil quality (e.g. organic C fractions, soil enzymatic activities, etc.) or the increase in the yield-scaled greenhouse gas emissions highlight the importance of avoiding the use of inversion tillage in the Mediterranean dryland areas (Melero et al., 2011; Plaza-Bonilla et al., 2014). On the other side, SWS tended to be greater under NT, especially at Agramunt and Selvanera, the sites with lower rainfall during the storage period. Water was stored deep in the soil profile under this tillage system where, preserved from soil evaporation, remains available for the crop during the consumption period. Similarly, other authors have reported greater water storage at soil depth under conservation tillage in semiarid conditions (O’Leary and Connor, 1997; Su et al., 2007).

Although related, differences in SWC between tillage systems were greater than differences in SWS. Throughout the year, SWC, and hence soil water potential, were in general greater under conservation tillage systems (NT and MT) than under more intensive tillage systems. This could explain the higher WUEs observed under conservation tillage systems, especially at Agramunt (Cantero-Martínez and Lampurlanés, 2007).

The significant relationships found between SWS and yield at Agramunt and Selvanera can be used to predict the yield of the year. This prediction would be more reliable at Selvanera than at Agramunt where yield predictions would fail in years with less than $100 \mathrm{~mm}$ SWS and more than $100 \mathrm{~mm}$ precipitation between tillering and anthesis (45\% of the years). Since SWS can be computed at tillering, this yield prediction can be a valuable tool to decide the amount of $\mathrm{N}$ fertilization to be used as top-dressing application. 


\section{Conclusions}

This long-term experiment demonstrates that, under semiarid rainfed conditions, soil water storage increases with the use of conservation tillage systems which leave more crop residues on the soil surface. Moreover, this effect increases when increasing the degree of aridity of the site. Inversion tillage should be avoided in these conditions, especially in soils prone to crust formation, because it can have deleterious effects on infiltration reducing their capacity to store water, leading to reduced crop yield. The relationship between water stored in the soil and crop yield and its reliability are site-specific. Once determined, it can be used to predict crop yield at the end of the vegetative phase of the crop. This can be a valuable tool to take management decisions like $\mathrm{N}$ fertilization.

\section{Acknowledgements}

This work was funded by the Comisión Interministerial de Ciencia y Tecnología (CICYT) of the Spanish Government, AGR91-312, AGF94-198, AGF98-261-C02, AGL2001-2238-CO2-02, AGL2004-7763-C02-01, AGL2007-66320-C02-01, AGL-2010-22050-C03-01, AGL2013-49062C4-1 projects. We also thank the farmers that collaborate in the development of the project, Josep Maria Besora, Josep Gabernet and Jaume Ramón. We especially acknowledge Jaume Gregori for his involvement and technical support during the development of the experiments. 


\section{References}

Álvaro-Fuentes, J., Arrúe, J.L., Gracia, R., López, M.V., 2008. Tillage and cropping intensification effects on soil aggregation: Temporal dynamics and controlling factors under semiarid conditions. Geoderma 145, 390-396.

Álvaro-Fuentes, J., Lampurlanés, J., Cantero-Martínez, C., 2009a. Alternative Crop Rotations under Mediterranean No-Tillage Conditions: Biomass, Grain Yield, and Water-Use Efficiency. Agron. J. 101, 1227-1233.

Álvaro-Fuentes, J., López, M.V., Arrúe, J.L., Moret, D., Paustian, K., 2009b. Tillage and cropping effects on soil organic carbon in Mediterranean semiarid agroecosystems: Testing the Century model. Agric. Ecosys. Environ. 134, 211-217.

Austin, R.B., Cantero-Martínez, C., Arrúe, J.L., Playán, E., Cano-Marcellán, P., 1998. Yield-rainfall relationships in cereal cropping systems in the Ebro river valley of Spain. Eur. J. Agron 8, 239248.

Bond, J.J., Willis, W.O., 1971. Soil water evaporation: long-term drying as influenced by surface residue and evaporation potential. Soil Sci. Soc. Am. Proc. 35, 984-987.

Campbell, G.S., Mulla, D.J., 1990. Measurement of soil water content and potential. In Irrigation of agricultural crops, pp. 127-141. Eds B.A. Stewart and D. R. Nielsen. Madison, USA: ASACSSA-SSSA.

Cantero-Martínez, C., Angás, P., Lampurlanés, J., 2003. Growth, yield and water productivity of barley (Hordeum vulgare L.) affected by tillage and $\mathrm{N}$ fertilization in Mediterranean semiarid, rainfed conditions of Spain. Field Crops Res. 84, 341-357.

Cantero-Martínez, C., Gabiña, D., Evaluation of agricultural practices to improve efficiency and environment conservation in Mediterranean arid and semi-arid production systems: MEDRATE project. In: Cantero-Martínez, C., Gabiña, D., (Eds.). 2004. Mediterranean Rainfed Agriculture: Strategies for Sustainability. Options Mediteranées. Serie A. Vol. 60. Zaragoza, Spain: CIHEAM. 
$335 \mathrm{pp}$.

Cantero-Martínez, C., Lampurlanés, J., 2007. Long-term yield and water use efficiency under various tillage systems in Mediterranean rainfed conditions. Ann Appl Biol 150, 293-305.

Cooper, P.J.M, Gregory, P.J., Tully, D., Harris, H.C., 1987. Improving water use efficiency of annual crops in the rainfed farming systems of west Asia and North Africa. Expl. Agric. 23, 113-158.

de Mendiburu, F., 2014. agricolae: Statistical Procedures for Agricultural Research. R package version 1.2-1. http://CRAN.R-project.org/package=agricolae

Delgado, J.A., Nearing, M.A., Rice, C.W., 2013. Conservation practices for climate change adaptation. Adv. Agron. 121, 47-115.

Fox, J. and Weisberg, S., 2011. An $\{\mathrm{R}\}$ Companion to Applied Regression, Second Edition. Thousand Oaks CA: Sage. URL: http://socserv.socsci.mcmaster.ca/jfox/Books/Companion.

García-Ruiz, J.M., 2010. The effects of land uses on soil erosion in Spain: A review. Catena 81, 111.

Hernanz, J.L., Sánchez-Girón, V., Navarrete, L., Sánchez, M.J., 2014. Long-term (1984-2012) assessment of three tillage systems on the energy use efficiency, crop production and seeding emergence in a rain fed cereal monoculture in semiarid conditions in central Spain. Field Crops Res. 166, 26-37.

Hudson, B.D., 1994. Soil organic matter and available water capacity. J. Soil Water Conserv. 49, 189-194.

Lahmar, R., Bationo, B.A., Lamso, N.D., Guéro, Y., Tittonell, P., 2012. Tailoring conservation agriculture technologies to West Africa semi-arid zones: Building on traditional local practices for soil restoration. Field Crop Res. 132, 158-167.

Lampurlanés, J., Angás, P., Cantero-Martínez, C., 2002. Tillage effect on water storage efficiency during fallow, and soil water content, root growth and yield of the following barley crop on two different soils in semiarid conditions. Soil Till. Res. 65, 207-220. 
Melero, S., Panettieri, M., Madejón, E., MacPherson, H., Moreno, F., Murillo, J.M., 2011. Implementation of chiselling and mouldboard ploughing in soil after 8 years of no-till management in SW, Spain: Effect on soil quality. Soil Till. Res. 112, 107-113.

Montenegro, A.A.A., Abrantes, J., de Lima, J., Singh, V.P., Santos, T.E.M., 2013. Impact of mulching on soil and water dynamics under intermittent simulated rainfall. Catena 109, 139-149.

Moret, D., Arrue, J.L., López, M.V., Gracia, R., 2006. Influence of fallowing practices on soil water and precipitation storage efficiency in semiarid Aragon (NE Spain). Agr. Water Manage. 82, 161176.

O'Leary, G.J., Connor, D.J., 1997. Stubble retention and tillage in a semi-arid environment: 1. Soil water accumulation during fallow. Field Crop Res. 52, 209-219.

Pagliai, M., Raglione, M., Panini, T., Maletta, M., La Marca M., 1995. The structure of two alluvial soils in Italy after 10 years of conventional and minimum tillage. Soil and Tillage Research 34, 209-223.

Papadakis, J. 1966. Climates of the World and their Agricultural Potentialities. Buenos Aires, Argentina: Editorial Albatros. 174 pp.

Peterson, G.A., Westfall, D.G., 2004. Managing precipitation use in sustainable dryland agroecosystems. Ann. Appl. Bio. 144, 127-138.

Plaza-Bonilla, D., Álvaro-Fuentes, J., Arrúe, J.L., Cantero-Martínez, C., 2014. Tillage and nitrogen fertilization effects on nitrous oxide yield-scale emissions in a rainfed Mediterranean area. Agric. Ecosys. Environ. 189, 43-52.

Plaza-Bonilla, D., Arrúe, J.L., Cantero-Martínez, C., Fanlo, R., Iglesias, A., Álvaro-Fuentes, J., 2015. Carbon management in dryland agricultural systems. A review. Agron. Sustain. Dev. 35,13191334. DOI:10.1007/s13593-015-0326-X. 
Plaza-Bonilla, D., Cantero-Martínez, C., Álvaro-Fuentes, J., 2010. Tillage effects on soil aggregation and soil organic carbon profile distribution under Mediterranean semi-arid conditions. Soil Use Manage. 26, 465-474.

Plaza-Bonilla, D., Cantero-Martínez, C., Viñas, P., Álvaro-Fuentes, J., 2013. Soil aggregation and organic carbon protection in a no-tillage chronosequence under Mediterranean conditions. Geoderma 193-194, 76-82.

R Development Core Team. 2015. R: A language and environment for statistical computing. R Foundation for Statistical Computing, Vienna, Austria. URL http://www.R-project.org/.

Radford, B.J., Gibson, G., Nielsen, R.G.H., Butler, D.G., Smith, G.D. Orange, D.N., 1992. Fallowing practices, soil water storage, plant-available soil nitrogen accumulation and wheat performance in South West Queensland. Soil Till. Res. 22, 73-93.

Smika, D.E., Unger, P.W., 1986. Effect of surface residues on soil water storage. Adv. Soil Sci. 5, 111-138.

Soil Survey Staff. 1999. Soil taxonomy: A basic system of soil classification for making and interpreting soil surveys. 2nd edition. Natural Resources Conservation Service. U.S. Department of Agriculture Handbook 436. 871 pp.

Su, Z., Zhang, J., Wu, W., Cai, D., Lv, J., Jiang, G., Huang, J., Gao, J., Hartmann, R., Gabriels, D., 2007. Effects of conservation tillage practices on winter wheat water-use efficiency and crop yield on the Loess Plateau, China. Agric. Water Manage. 87, 307-314.

Swella, G.B., Ward, P.R., Siddique, K.H.M., Flower, K.C., 2015. Combinations of tall standing and horizontal residue affects soil water dynamics in rainfed conservation agriculture systems. Soil Till. Res. 147, 30-38.

Tanaka, D.L., Anderson, R.L. 1997. Soil water storage and precipitation storage efficiency of conservation tillage systems. J. Soil Water Cons 52, 363-367. 
Thomas, G.A., Titmarsh, G.W., Freebairn, D.M., Radford, B.J., 2007. No-tillage and conservation farming practices in grain growing areas of Queensland - a review of 40 years of development. Aust J Exp Agr 47, 887-898.

Unger, P.W., McCalla, T.M., 1980. Conservation tillage systems. Adv. Agron. 33, 1-58.

Zapater, M.A., 1995. Agroclimatología de la Segarra y condicionantes climáticos de la producción de cebada. PFC. Lleida, Spain: Universitat de Lleida. 310 pp. 
Table 1. Site and general soil characteristics in the $0-30 \mathrm{~cm}$ soil depth of the three experimental sites.

\begin{tabular}{|c|c|c|c|}
\hline & El Canós & Agramunt & Selvanera \\
\hline Year of establishment & 1992 & 1990 & 1987 \\
\hline Latitude & $41^{\circ} 41^{\prime} \mathrm{N}$ & $41^{\circ} 48^{\prime} \mathrm{N}$ & $41^{\circ} 49^{\prime} \mathrm{N}$ \\
\hline Longitude & $1^{\circ} 12^{\prime} \mathrm{E}$ & $1^{\circ} 07^{\prime} \mathrm{E}$ & $1^{\circ} 17^{\prime} \mathrm{E}$ \\
\hline Elevation (m) & 410 & 330 & 480 \\
\hline Mean annual precipitation $(\mathrm{mm})^{\mathrm{a}}$ & 382 & 432 & 450 \\
\hline Mean annual ETo $(\mathrm{mm})^{\mathrm{a}}$ & 797 & 855 & 800 \\
\hline Mean annual water deficit $(\mathrm{mm})^{\mathrm{b}}$ & 415 & 423 & 350 \\
\hline Soil classification $^{\mathrm{c}}$ & Fluventic Xerochrept & Typic Xerochrept & Fluventic Xerochrept \\
\hline $\mathrm{pH}\left(\mathrm{H}_{2} \mathrm{O}, 1: 2.5\right)$ & 8.2 & 8.5 & 8.3 \\
\hline Soil organic carbon $\left(\mathrm{g} \mathrm{kg}^{-1}\right)$ & 13.9 & 7.6 & 10.5 \\
\hline EC $1: 5\left(\mathrm{dS} \mathrm{m}^{-1}\right)$ & 0.19 & 0.15 & 0.16 \\
\hline Equivalent $\mathrm{CaCO}_{3}(\%)$ & 25 & 40 & 35 \\
\hline Water-holding capacity $(\mathrm{mm})^{\mathrm{d}}$ & 225 & 206 & 213 \\
\hline \multicolumn{4}{|l|}{ Particle size distribution (\%) } \\
\hline Sand $(2,000-50 \mu \mathrm{m})$ & 24.9 & 30.2 & 36.5 \\
\hline Silt $(50-2 \mu \mathrm{m})$ & 52.7 & 51.9 & 46.4 \\
\hline Clay $(<2 \mu \mathrm{m})$ & 22.6 & 17.9 & 17.1 \\
\hline
\end{tabular}

${ }^{\text {a }}$ From Zapater, 1995.

${ }^{\mathrm{b}}$ Difference between mean annual ETo and mean annual precipitation.

${ }^{c}$ According to the USDA classification (Soil Survey Staff, 1999).

${ }^{\mathrm{d}}$ Up to $1 \mathrm{~m}$ (soil sampling depth). 
Table 2. Crops at El Canós, Agramunt and Selvanera from 1987 to 2014.

\begin{tabular}{cccc}
\hline $\begin{array}{c}\text { Growing } \\
\text { Season }\end{array}$ & El Canós & Agramunt & Selvanera \\
\hline $1987-1988$ & & & \\
$1988-1989$ & - & - & Barley \\
$1989-1990$ & - & - & Barley \\
$1990-1991$ & - & Barley & Barley \\
$1991-1992$ & - & Barley & Barley \\
$1992-1993$ & Barley & Barley & Canola \\
$1993-1994$ & Barley & Barley & Wheat \\
$1994-1995$ & Barley & Barley & Barley \\
$1995-1996$ & Barley & Barley & Barley \\
$1996-1997$ & Barley & Barley & Canola \\
$1997-1998$ & Barley & Barley & Wheat \\
$1998-1999$ & Barley & Barley & Barley \\
$1999-2000$ & Barley & Barley & Wheat \\
$2000-2001$ & Barley & Wheat & Canola \\
$2001-2002$ & - & Barley & Wheat \\
$2002-2003$ & - & Wheat & Barley \\
$2003-2004$ & - & Barley & Wheat \\
$2004-2005$ & - & Wheat & Canola \\
$2005-2006$ & - & Barley & Wheat \\
$2006-2007$ & - & Wheat & Barley \\
$2007-2008$ & - & Triticale & Wheat \\
$2008-2009$ & - & Barley & Canola \\
$2009-2010$ & - & Wheat & Wheat \\
$2010-2011$ & - & Barley & Barley \\
$2011-2012$ & - & Wheat & Pea \\
$2012-2013$ & - & Triticale & Wheat \\
$2013-2014$ & - & Wheat & Canola \\
\hline
\end{tabular}

Grey data indicate growing seasons not included in the analysis because of lack of data on soil water content. 
Table 3. ANOVA for soil water content (SWC) at different crop development stages.

\begin{tabular}{|c|c|c|c|c|c|}
\hline \multirow{2}{*}{$\begin{array}{l}\text { Location } \\
\text { ANOVA factors }\end{array}$} & \multicolumn{5}{|c|}{ Probability values } \\
\hline & Prev. Harvest & Sowing & Tillering & Anthesis & Harvest \\
\hline \multicolumn{6}{|l|}{ El Canós } \\
\hline YEAR & $<0.0001$ & $<0.0001$ & $<0.0001$ & $<0.0001$ & $<0.0001$ \\
\hline TIL & 0.008 & 0.003 & 0.007 & NS & 0.004 \\
\hline TIL*YEAR & NS & NS & NS & NS & NS \\
\hline \multicolumn{6}{|l|}{ Tillage means: } \\
\hline NT & $188 \mathrm{a}$ & $227 \mathrm{a}$ & $272 \mathrm{a}$ & 212 & $185 \mathrm{a}$ \\
\hline MT & $182 \mathrm{~b}$ & $217 \mathrm{~b}$ & $265 \mathrm{~b}$ & 209 & $180 \mathrm{ab}$ \\
\hline Sub-50 & $180 \mathrm{~b}$ & $211 \mathrm{~b}$ & $262 \mathrm{~b}$ & 204 & $174 \mathrm{~b}$ \\
\hline \multicolumn{6}{|l|}{ Agramunt } \\
\hline YEAR & $<0.0001$ & $<0.0001$ & $<0.0001$ & $<0.0001$ & $<0.0001$ \\
\hline TIL & $<0.0001$ & $<0.0001$ & $<0.0001$ & $<0.0001$ & $<0.0001$ \\
\hline TIL*YEAR & NS & $<0.0001$ & 0.02 & NS & NS \\
\hline \multicolumn{6}{|l|}{ Tillage means: } \\
\hline NT & $124 \mathrm{a}$ & $139 \mathrm{a}$ & $214 \mathrm{a}$ & $164 \mathrm{a}$ & $122 \mathrm{a}$ \\
\hline $\mathrm{Ch}$ & $111 \mathrm{~b}$ & $126 \mathrm{~b}$ & $197 \mathrm{~b}$ & $148 \mathrm{bc}$ & $110 \mathrm{~b}$ \\
\hline Sub-50 & $112 \mathrm{~b}$ & $127 \mathrm{~b}$ & $197 \mathrm{~b}$ & $152 \mathrm{~b}$ & $111 \mathrm{~b}$ \\
\hline $\mathrm{Mb}$ & $111 \mathrm{~b}$ & 119 & $181 \mathrm{c}$ & $144 \mathrm{c}$ & $111 \mathrm{~b}$ \\
\hline \multicolumn{6}{|l|}{ Selvanera } \\
\hline YEAR & $<0.0001$ & $<0.0001$ & $<0.0001$ & $<0.0001$ & $<0.0001$ \\
\hline TIL & $<0.0001$ & $<0.0001$ & $<0.0001$ & $<0.0001$ & $<0.0001$ \\
\hline TIL*YEAR & NS & $<0.0002$ & $<0.0002$ & NS & NS \\
\hline \multicolumn{6}{|l|}{ Tillage means: } \\
\hline NT & $154 \mathrm{~b}$ & $163 \mathrm{~b}$ & $254 \mathrm{a}$ & $197 \mathrm{ab}$ & $153 \mathrm{~b}$ \\
\hline MT & $160 \mathrm{a}$ & $177 \mathrm{a}$ & $256 \mathrm{a}$ & $201 \mathrm{a}$ & $160 \mathrm{a}$ \\
\hline Sub-25 & 148 & $158 \mathrm{~b}$ & $245 \mathrm{~b}$ & 187 & 146 \\
\hline Sub-50 & $150 \mathrm{bc}$ & $161 \mathrm{~b}$ & $241 \mathrm{~b}$ & $192 \mathrm{bc}$ & $150 \mathrm{bc}$ \\
\hline
\end{tabular}

TIL, tillage system: no-tillage (NT), minimum tillage (MT), and subsoiler at 25 and $50 \mathrm{~cm}$ depth (Sub-25 and Sub-50, respectively).

NS, no significant at the 0.05 probability level. 
Table 4. ANOVA, general mean and tillage means for soil water storage (SWS), precipitation storage efficiency (PSE), post-tillering evapotranspiration (ET), and yield at El Canós.

\begin{tabular}{|c|c|c|c|c|c|c|c|c|c|c|}
\hline \multirow{2}{*}{$\begin{array}{l}\text { El Canós } \\
\text { ANOVA table }\end{array}$} & \multicolumn{3}{|c|}{$\begin{array}{l}\text { SWS } \\
(\mathbf{m m})\end{array}$} & \multicolumn{3}{|c|}{$\begin{array}{l}\text { PSE } \\
(\%)\end{array}$} & \multicolumn{3}{|c|}{ Post-tillering ET (mm) } & \multirow[t]{2}{*}{$\begin{array}{c}\text { Yield } \\
\left(\mathrm{kg} \mathrm{ha}^{-1}\right)\end{array}$} \\
\hline & PH to $\mathrm{S}$ & $\mathrm{S}$ to $\mathrm{T}$ & Whole period & PH to $\mathrm{S}$ & $\mathrm{S}$ to $\mathrm{T}$ & Whole period & $\mathrm{T}$ to $\mathrm{A}$ & A to $\mathrm{H}$ & Whole period & \\
\hline YEAR & $<0.0001$ & $<0.0001$ & $<0.0001$ & $<0.0001$ & $<0.0001$ & $<0.0001$ & $<0.0001$ & $<0.0001$ & $<0.0001$ & $<0.0001$ \\
\hline TIL & NS & NS & NS & NS & NS & NS & NS & NS & NS & NS \\
\hline TIL*YEAR & NS & NS & NS & NS & NS & NS & NS & NS & 0.02 & NS \\
\hline General mean & 35 & 48 & 83 & 29 & 38 & 32 & 99 & 116 & 227 & $3239 \pm 1004$ \\
\hline \multicolumn{11}{|l|}{ Tillage means } \\
\hline NT & 39 & 45 & 84 & 31 & 39 & 33 & 101 & 115 & 227 & $3304 \pm 1040 *$ \\
\hline MT & 35 & 48 & 83 & 30 & 35 & 32 & 98 & 116 & 225 & $3266 \pm 948$ \\
\hline Sub-50 & 31 & 52 & 83 & 27 & 40 & 32 & 99 & 118 & 228 & $3146 \pm 1053$ \\
\hline
\end{tabular}

ET, evapotranspiration.

* mean values \pm standard deviation.

$\mathrm{PH}$ to $\mathrm{S}$, previous harvest to sowing.

$\mathrm{S}$ to $\mathrm{T}$, sowing to tillering.

$\mathrm{T}$ to $\mathrm{A}$, tillering to anthesis.

A to $\mathrm{H}$, anthesis to harvest.

TIL, tillage system: no-tillage (NT), minimum tillage (MT), and subsoiler at $50 \mathrm{~cm}$ depth (Sub-50).

NS, not significant at the 0.05 probability level.

Different letters indicate significant differences between tillage systems at $P<0.05$. 
Table 5. ANOVA table, general mean and tillage means for soil water storage (SWS), precipitation storage efficiency (PSE), post-tillering evapotranspiration (ET), and yield at Agramunt.

\begin{tabular}{|c|c|c|c|c|c|c|c|c|c|c|}
\hline \multirow{2}{*}{$\begin{array}{l}\text { Agramunt } \\
\text { ANOVA table }\end{array}$} & \multicolumn{3}{|c|}{$\begin{array}{l}\text { SWS } \\
(\mathrm{mm})\end{array}$} & \multicolumn{3}{|c|}{$\begin{array}{l}\text { PSE } \\
(\%)\end{array}$} & \multicolumn{3}{|c|}{ Post-tillering ET (mm) } & \multirow[t]{2}{*}{$\begin{array}{c}\text { Yield } \\
\left(\mathrm{kg} \mathrm{ha}^{-1}\right)\end{array}$} \\
\hline & $\mathrm{PH}$ to $\mathrm{S}$ & $\mathrm{S}$ to $\mathrm{T}$ & Whole period & $\mathrm{PH}$ to $\mathrm{S}$ & $\mathrm{S}$ to $\mathrm{T}$ & Whole period & $\mathrm{T}$ to $\mathrm{A}$ & A to $\mathrm{H}$ & Whole period & \\
\hline YEAR & $<0.0001$ & $<0.0001$ & $<0.0001$ & $<0.0001$ & $<0.0001$ & $<0.0001$ & $<0.0001$ & $<0.0001$ & $<0.0001$ & $<0.0001$ \\
\hline TIL & 0.004 & $<0.0001$ & $<0.0001$ & $<0.0001$ & 0.003 & $<0.0001$ & 0.0008 & NS & $<0.0001$ & $<0.0001$ \\
\hline TIL*YEAR & $<0.0001$ & $<0.0001$ & 0.005 & $<0.0001$ & $<0.0001$ & $<0.0001$ & 0.02 & NS & 0.01 & $<0.0001$ \\
\hline General mean & 14 & 70 & 81 & 29 & 46 & 37 & 174 & 125 & 286 & $2644 \pm 1218$ \\
\hline \multicolumn{11}{|l|}{ Tillage means } \\
\hline NT & $16 \mathrm{a}$ & $76 \mathrm{a}$ & $87 \mathrm{a}$ & $34 \mathrm{a}$ & $50 \mathrm{a}$ & $42 \mathrm{a}$ & $177 \mathrm{a}$ & 127 & $295 \mathrm{a}$ & $2929 \pm 1204 \mathrm{a}^{*}$ \\
\hline $\mathrm{Ch}$ & $16 \mathrm{a}$ & $72 \mathrm{ab}$ & $84 \mathrm{a}$ & $31 \mathrm{ab}$ & $47 \mathrm{~b}$ & $38 \mathrm{~b}$ & $178 \mathrm{a}$ & 125 & $290 \mathrm{ab}$ & $2508 \pm 1055$ \\
\hline Sub-50 & $16 \mathrm{a}$ & $69 \mathrm{~b}$ & $82 \mathrm{a}$ & $28 \mathrm{~b}$ & $46 \mathrm{~b}$ & $37 \mathrm{~b}$ & $176 \mathrm{a}$ & 127 & $287 \mathrm{~b}$ & $2708 \pm 1180 b$ \\
\hline $\mathrm{Mb}$ & $8 \mathrm{~b}$ & $62 \mathrm{c}$ & $70 \mathrm{~b}$ & $22 \quad \mathrm{c}$ & $42 \mathrm{c}$ & $32 \quad \mathrm{c}$ & $166 \mathrm{~b}$ & 121 & 273 & $2430 \pm 1432$ \\
\hline
\end{tabular}

ET, evapotranspiration.

* mean values \pm standard deviation.

$\mathrm{PH}$ to S, previous harvest to sowing.

$\mathrm{S}$ to $\mathrm{T}$, sowing to tillering.

$\mathrm{T}$ to A, tillering to anthesis.

A to $\mathrm{H}$, anthesis to harvest.

TIL, tillage system: no-tillage (NT), chisel (Ch), subsoiler $50 \mathrm{~cm}$ depth (Sub-50), and mouldboard plough (Mb).

NS, no significant at the 0.05 probability level.

Different letters indicate significant differences between tillage systems at $P<0.05$.

1 
Table 6. ANOVA table, general mean and tillage means for soil water storage (SWS), precipitation storage efficiency (PSE), post-tillering evapotranspiration (ET), and yield at Selvanera.

\begin{tabular}{|c|c|c|c|c|c|c|c|c|c|c|}
\hline \multirow{2}{*}{$\begin{array}{l}\text { Selvanera } \\
\text { ANOVA table }\end{array}$} & \multicolumn{3}{|c|}{$\begin{array}{l}\text { SWS } \\
(\mathrm{mm})\end{array}$} & \multicolumn{3}{|c|}{$\begin{array}{l}\text { PSE } \\
(\%)\end{array}$} & \multicolumn{3}{|c|}{$\begin{array}{c}\begin{array}{c}\text { Post-tillering ET } \\
(\mathrm{mm})\end{array} \\
\end{array}$} & \multirow[t]{2}{*}{$\begin{array}{c}\text { Yield } \\
\left(\mathrm{kg} \mathrm{ha}^{-1}\right)\end{array}$} \\
\hline & $\mathrm{PH}$ to $\mathrm{S}$ & $\mathrm{S}$ to $\mathrm{T}$ & Whole period & $\mathrm{PH}$ to $\mathrm{S}$ & $\mathrm{S}$ to $\mathrm{T}$ & Whole period & $\mathrm{T}$ to $\mathrm{A}$ & A to $\mathrm{H}$ & Whole period & \\
\hline YEAR & $<0.0001$ & $<0.0001$ & $<0.0001$ & $<0.0001$ & $<0.0001$ & $<0.0001$ & $<0.0001$ & $<0.0001$ & $<0.0001$ & $<0.0001$ \\
\hline TIL & NS & NS & NS & 0.04 & NS & 0.01 & NS & NS & NS & 0.05 \\
\hline TIL*YEAR & 0.005 & 0.05 & 0.002 & NS & NS & 0.0006 & NS & NS & 0.03 & $<0.0001$ \\
\hline General mean & 12 & 92 & 99 & 32 & 61 & 49 & 163 & 135 & 298 & $4310 \pm 1692$ \\
\hline \multicolumn{11}{|l|}{ Tillage means } \\
\hline NT & 8 & 98 & 104 & $32 \mathrm{ab}$ & 65 & $51 \mathrm{a}$ & 162 & 126 & 286 & $4393 \pm 1656 \mathrm{a}^{*}$ \\
\hline MT & 18 & 87 & 99 & $38 \mathrm{a}$ & 58 & $48 \mathrm{~b}$ & 164 & 137 & 300 & $4355 \pm 1733 \mathrm{ab}$ \\
\hline Sub-25 & 11 & 93 & 97 & $28 \mathrm{~b}$ & 60 & $48 \mathrm{~b}$ & 166 & 132 & 296 & $4269 \pm 1681 \quad b c$ \\
\hline Sub-50 & 9 & 90 & 96 & $28 \mathrm{~b}$ & 58 & $46 \mathrm{~b}$ & 161 & 135 & 296 & $4219 \pm 1738 \quad \mathrm{c}$ \\
\hline
\end{tabular}

ET, evapotranspiration.

* mean values \pm standard deviation.

$\mathrm{PH}$ to $\mathrm{S}$, previous harvest to sowing.

$\mathrm{S}$ to $\mathrm{T}$, sowing to tillering.

$\mathrm{T}$ to $\mathrm{A}$, tillering to anthesis.

A to $\mathrm{H}$, anthesis to harvest.

TIL, tillage system: no-tillage (NT), chisel (Ch), subsoiler at $50 \mathrm{~cm}$ depth (Sub-50), and mouldboard plough (Mb).

NS, no significant at the 0.05 probability level.

Different letters indicate significant differences between tillage systems at $P<0.05$. 


\section{Figure captions}

2

3 Fig. 1 Periods and sub-periods of the growing cycle: previous harvest to sowing ( $\mathrm{PH}$ to

$4 \mathrm{~S}$ ), sowing to tillering ( $\mathrm{S}$ to $\mathrm{T}$ ), tillering to anthesis ( $\mathrm{T}$ to $\mathrm{A}$ ) and anthesis to harvest (A 5 to $\mathrm{H})$.

6

7 Fig. 2 Rainfall from July of the sowing year to June of the harvest year during the

8 different cropping seasons studied at El Canós, Agramunt and Selvanera.

10 Fig. 3 Mean rainfall distribution at El Canós, Agramunt and Selvanera as an average of 11 the cropping seasons (shown at the top) for different sub-periods: harvest of the 12 previous crop to sowing ( $\mathrm{PH}$ to $\mathrm{S}$ ), sowing to tillering ( $\mathrm{S}$ to $\mathrm{T}$ ), tillering to anthesis ( $\mathrm{T}$ to 13 A), and anthesis to harvest (A to $\mathrm{H}$ ).

15 Fig. 4 Soil water content ( up to $100 \mathrm{~cm}$ depth) at tillering (lines) and previous harvest 16 to tillering rainfall (columns) at a) Agramunt and b) Selvanera for the different tillage 17 systems: no-tillage (NT), chisel (Ch), subsoiler at $50 \mathrm{~cm}(\mathrm{Sub}-50)$, and mouldboard 18 plough $(\mathrm{Mb})$. Within each cropping season, different letters indicate significant 19 differences between tillage systems at 0.05 probability level. In each site, the field 20 capacity (FC) and permanent wilting point (PWP) values are shown in dotted lines.

22 Fig. 5 Grain yield at a) El Canós, b) Agramunt and c) Selvanera for different tillage systems: no-tillage (NT), minimum tillage (MT), chisel (Ch), subsoiler at $25 \mathrm{~cm}$ (Sub-

24 25), subsoiler at $50 \mathrm{~cm}(\mathrm{Sub}-50)$, and mouldboard plough (Mb). Within each cropping 25 season, different letters indicate significant differences between tillage treatments at 
10.05 probability level. Capital letters over the bars stand for the crop sown each year:

2 barley (B), wheat (W), triticale (T), canola (C), and peas (P).

3

4 Fig. 6 Linear relationship between grain yield and soil water storage (SWS) up to 5 tillering in the experiments of Agramunt (a) and Selvanera (b) for the tillage treatments 6 compared (S50, subsoiler at $50 \mathrm{~cm}$; S25, subsoiler at $25 \mathrm{~cm}$; Ch, chisel; NT, no-tillage; 7 MT, minimum tillage; Mb, mouldboard plough). Year 2013 at Agramunt and years 82003 and 2011 at Selvanera (in light grey) were excluded from the regressions. Note the 9 different $\mathrm{Y}$-axis scales. 


Development
Phase

Fig. 1 


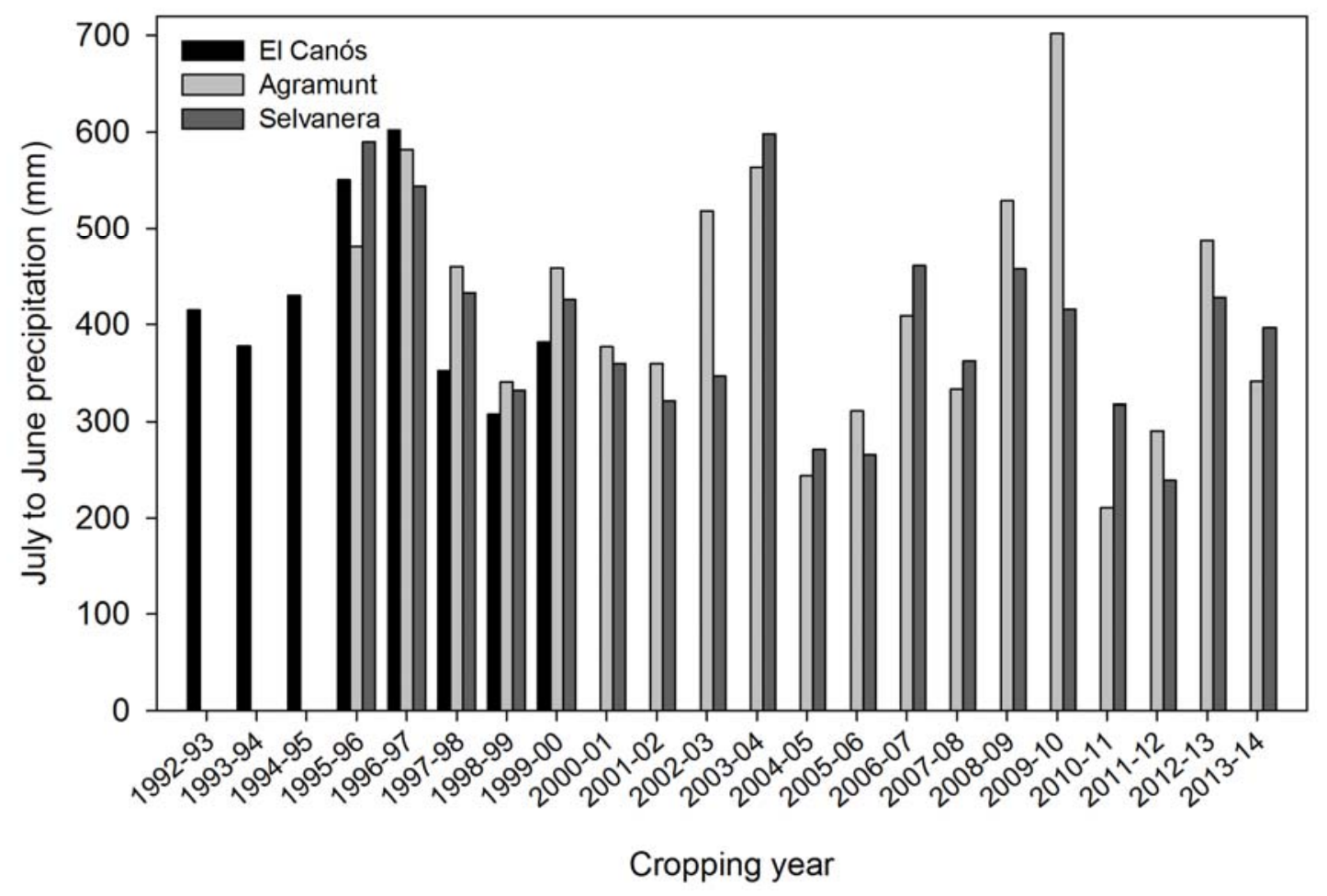

Fig. 2 


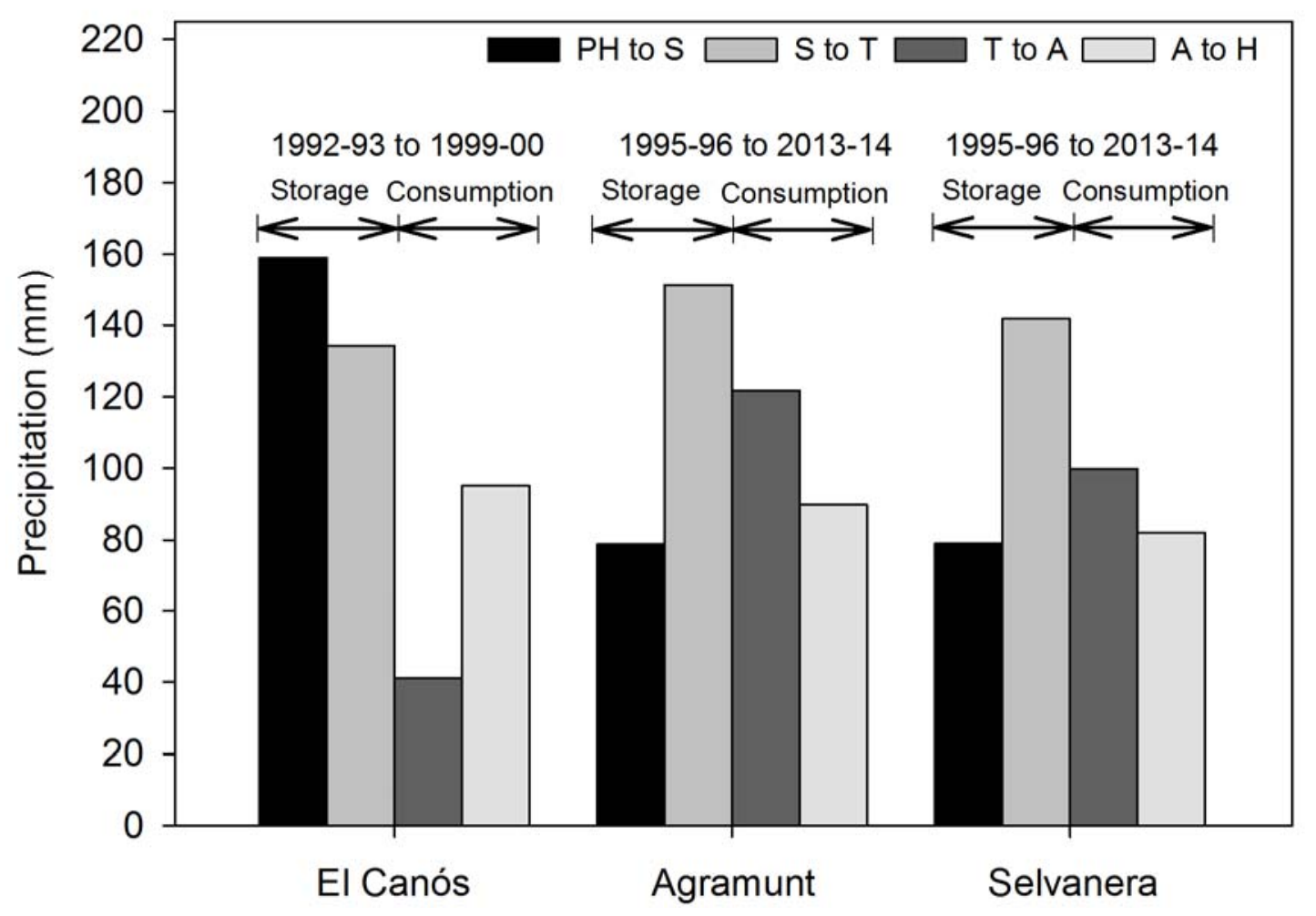

Fig. 3 

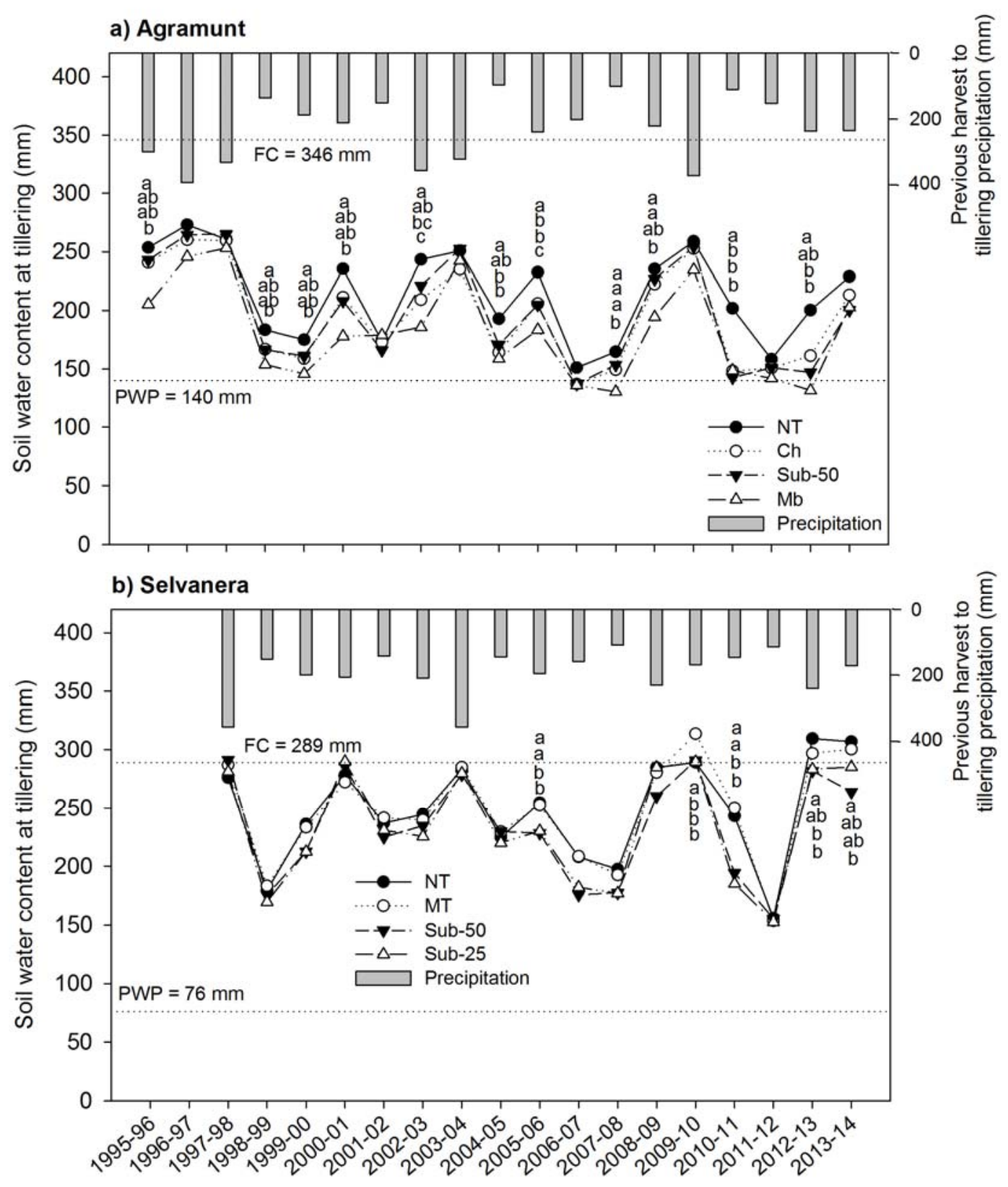

Fig. 4

Cropping season 

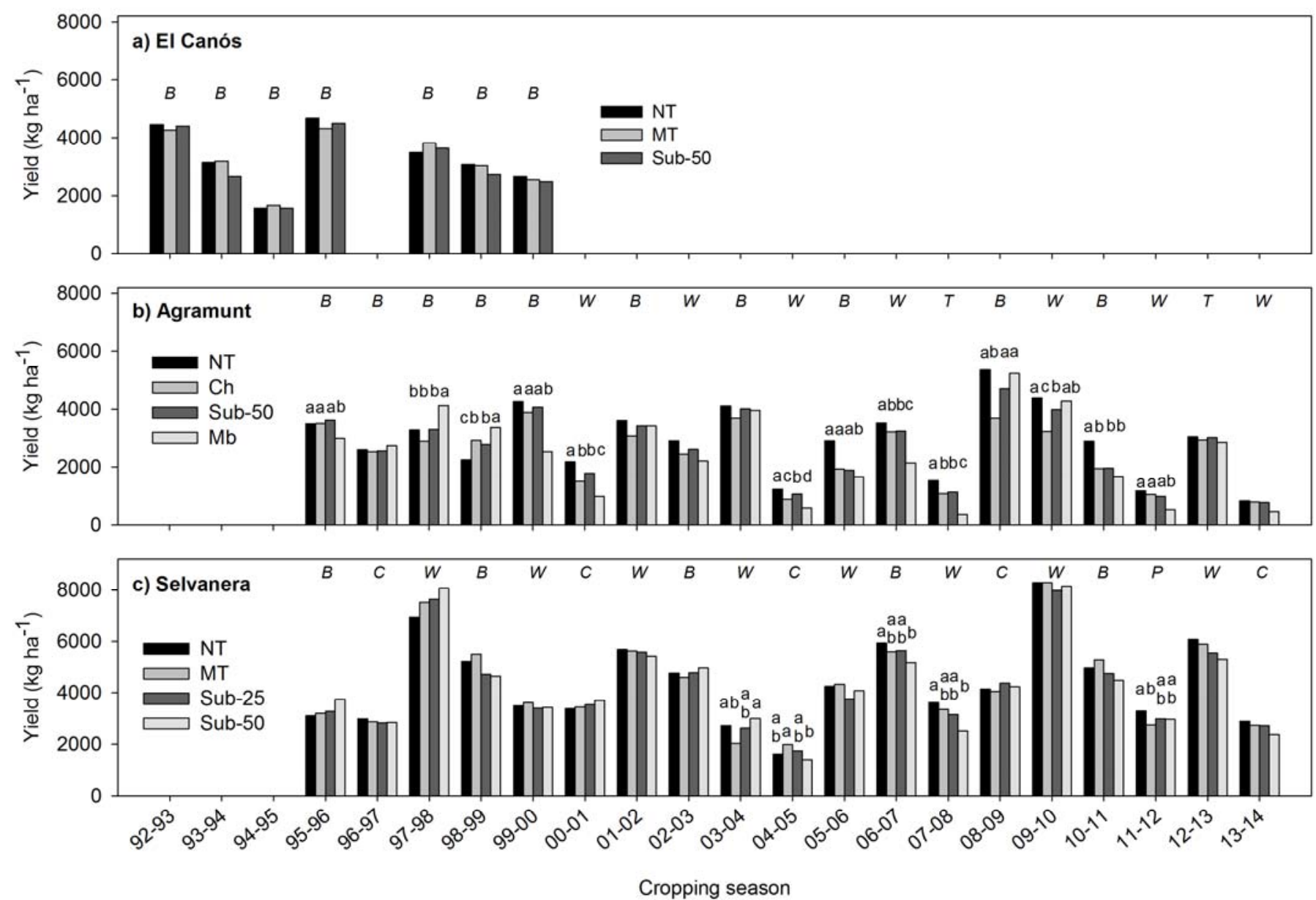

Fig. 5 

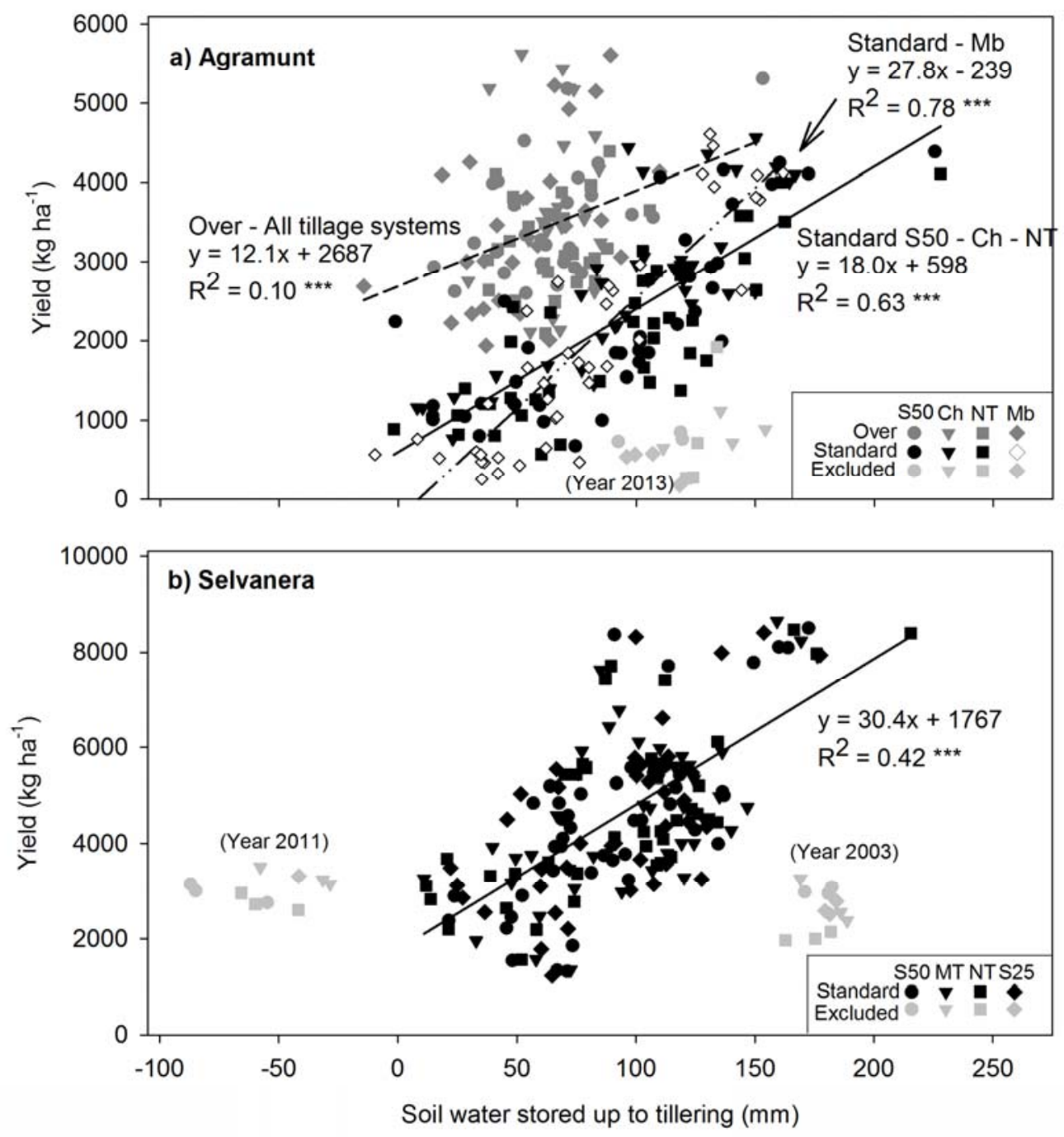

Fig. 6 